\title{
African Pastoralism: Plus ça Change? From Constant Herders to Social Differentiation
}

\author{
Clemens Greiner
}

$1 \quad$ Introduction

Concern about the future and survival of 'pastoralists' has been a pervasive and recurring theme in research on African pastoralism (Hodgson 2001). Starting from Sidney and Hildegarde Hinde's The Last of the Maasai bemoaning the "fast approaching extinction of the pure stock" (Hinde and Hinde 1901: 109, my emphasis), to the conference held in Nairobi in 1980 on the Future of Pastoral Peoples (Galaty et al. 1981), and to a recent Lands of the Future initiative (Abbink et al. 2014), researchers have been voicing their concerns about the future of people engaged in livestock herding in Africa.

This concern, I suggest, derives partially from an analytical gap in the research literature on the conceptualization (or lack thereof) of transformation processes. A key reason for this blind spot lies in an overemphasis on socio-ecological relations and a persistent framing of pastoralism as a pre-capitalist mode of production embraced by egalitarian, close-knit, environmentally adapted communities exploiting a unique ecological niche - in other words, 'pastoralists'. As a result of this narrow and homogenizing focus, change is mainly conceived of as a threat to the survival of 'traditional' livelihoods, typically triggered from outside forces that are largely uncontrolled by local people.

Research on East Africa in recent decades shows that many people who live predominantly from herding suffer from a range of factors that have led to increasing constraints on their rangelands and livestock-based economies (Anderson and Broch-Due 1999; Catley et al. 2013). The marginalization of such communities can often be traced to early colonial policies, with significant continuity under many post-independence governments. Yet, in recent decades, conservation projects (Homewood et al. 20o9), land privatization (Galaty 1994), infrastructural development (Lind et al. 2020), and violent conflicts (Mkutu 2008) - together with massive environmental changes - have contributed to a dramatic loss of open and accessible rangeland, as a crucial basis for extensive livestock herding (Galvin et al. 2008). Livelihood diversification (Little et al. 2001), sedentarization, and migration to towns (Fratkin and Roth 2005), as well as crop farming (McCabe et al. 2010), have all been described and analysed as major alternatives to specialized (nomadic) pastoralism.

(C) CLEMENS GREINER, 2022 | DOI:10.1163/9789004471641_005

This is an open access chapter distributed under the terms of the CC BY-NC 4.0 License.

Clemens Greiner - 9789004471641 
This is neither the place to expand on these studies nor to offer a comprehensive literature review. Rather, I take the liberty to address the research literature on 'pastoralists' as a genre to diagnose an epistemological problem and to argue that change is too often analysed within narrow frameworks. More precisely, transformation is often examined as an adaptation to externally imposed structural or ecological conditions. By contrast, themes of agency, internal social differentiation, and indigenous commodification have been largely overlooked. With some notable exceptions (for example Little 1992), this blind spot in the literature has only recently come into focus (Caravani 2018; Holtzman 2003; Korf et al. 2015; Scoones 2020). Scholars working on population growth and intensification (Moritz 2012), land-tenure change (Lesorogol 2008), poverty (Little et al. 2008), and gender relations (Hodgson 200o) have problematized these conceptual tendencies. Dorothy Hodgson, for example, critically remarks that the culture and gender relations of livestock herding people are often "presented as fixed immutable, outside of history and beyond change" (Hodgson 2000: 16)

In neighbouring fields, approaches in political economy have fundamentally shaken concepts of homogenous communities or ideas of isolated development. The 'Kalahari debate' in hunter-gatherer studies (Wilmsen 1989), or the epic debates on class formation in peasant studies (Bernstein 2010), are cases in point. The epistemic community of pastoralism researchers appears to lack such fundamental controversies over the nature of pastoralist communities and related issues of socio-economic change. Part of the problem is the self-referentiality of established research literature. Although research on 'pastoralists' embraces a wide field, including identity studies (Schlee 1989), Marxist approaches (Rigby 1985), new institutional economics (Ensminger 1992), or risk management (Bollig 2006), pastoralism is often considered to be a field of research in its own right, particularly in anthropology. As a consequence, the study of pastoralism (or pastoralists, for that matter) "has become isolated from wider developments in the discipline and related fields", as Peter Little (2014: 2) critically observes (cf. Scoones 2020). Another challenge, I argue here, is the predominance of research focusing on environmental adaptation, which has come to characterize the field of pastoralism studies. The following brief review of anthropological literature on (predominantly East African) pastoralism summarizes these trends.

This short chapter concludes with a suggestion to reflect critically on homogenizing tendencies of categories such as 'pastoralists', and instead to analyse socially differentiated societies engaged in agrarian livelihood strategies. Pastoralism, on the other hand, should be understood as a strictly descriptive term that refers to sets of practices that can be carried out to varying degrees, and 
in diverse forms, in rural as well as in (peri-)urban settings. This reframing can offer a more nuanced understanding of transformation dynamics among people engaged in pastoral livelihood strategies.

Anthropologists have for many decades portrayed 'pastorlists' - particularly East African ones - as generally egalitarian, self-regulating, persistent and conservative autonomous groups (Herskovits 1926; Schneider 1959; Spencer 1965). Interestingly, this has applied less to ethnographic accounts of pastoralism in other regions. Studies of Middle Eastern and circum-Mediterranean pastoralism, for example, tend to emphasize class stratification, shifts between different livelihood strategies, and interactions among nomads, sedentary populations, and the state (Barth 1961; Salzman 1980, 2004).

Ideal type descriptions of East African pastoralists as strongly bounded groups is at least partially due to the lasting influence of British structural functionalism and, as Rada and Neville Dyson-Hudson (1980: 16) observe, its "assumptions about the boundedness and stability of local systems". Structural functionalism, as the Dyson-Hudsons note, which had a particularly strong impact on studies of East African pastoralism, also "generally underestimated the impact of colonialism and involvement in the nation-state" (Dyson-Hudson and Dyson-Hudson 1980: 49). Written in 1940, E. E. Evans-Pritchard's seminal ethnography of the Nuer is certainly among the most prominent examples, especially as it relates culture and livelihoods to 'oecology' (Evans-Pritchard 1987: 51) or environmental conditions. This ecological connection, as I show below, is a thread that runs through research on pastoralism.

Julian Steward's idea of cultural ecology, which gained prominence in the 1950s and 1960s, buttressed this tendency with neo-functionalist assumptions and ecosystem approaches (Dyson-Hudson and Dyson-Hudson 1980). Following the work of Rappaport (1984) and others, human adaptation to ecological niches became a prominent focus. In a nutshell, the cultural ecology framework posits that environmental conditions in drylands are such that mobile livelihoods can only flexibly exploit resources that are sporadically available. Under such constraints, herders and their animals emerge as perfectly adapted units (Schareika 1994), with drylands appearing as the 'natural habitat' of pastoralists. The adaptation framework thus attributes the allegedly sturdy conservatism of pastoralists to the smooth functioning of their specialized culture, which is thought of as so deeply bound up with local ecology that every innovation potentially threatens this balance. 
This image of the constant herder started to crumble in the 1980s, when scholars increasingly observed a profound crisis among many African pastoral societies, triggered at least in part by catastrophic droughts that plagued many parts of Africa throughout this decade. Drought often occurred in tandem with steep demographic growth rates (Spencer 1998), which were further compounded by other factors, such as state intervention into property rights, restricted movement, and failed development projects (Fratkin 1991). Poverty and social differentiation came into focus (Little 1985), and Rada Dyson-Hudson (1980) suggested a 'general theory of stratification' for pastoralist societies, according to which access to arable land played a key role. These changes in the African drylands were famously termed the 'new pastoralism' by Richard Hogg (1986), to refer to marginalization and poverty.

During the 199os, non-equilibrium ecology emerged as a paradigmatic shift in ecosystems research (Zimmerer 1994). This new ecological thinking diverges from earlier perspectives that viewed ecosystems as balanced, equilibriumoriented, and characterized by linear succession and gradual change. By contrast, non-equilibrium approaches argue that ecosystems are generally characterized by variation, uncertainty, and dynamic change. These approaches explicitly included human activities, moreover, and were quickly adapted to research on pastoralism, for example, in the multidisciplinary South Turkana Ecosystem Project (McCabe 2004). Such interdisciplinary projects, focusing on savanna ecosystems and involving anthropology, ecology, and other sciences, became very prominent in research on (East) African pastoralism (Little 2003). Almost by default, they required a focus on relatively isolated, self-contained but now ecologically dynamic, rather than stable - systems.

With the new ecological thinking and resilience theory, which became important in the 20oos (Anderson and Bollig 2016), the adaptation framework regained prominence in research on African pastoralism. In the most recent contribution on pastoralism in the prominent Annual Review of Anthropology series, Kathleen Galvin (2009) bases her analysis on the adaptive capacity framework and informs readers that "pastoralists have adapted for centuries to climate, social, political, and ecological processes. ... They are still adapting" (Galvin 2009: 193).

As Michael Watts (2015: 35) notes, the adaptation concept, with its functionalist notions, was washed away with the rise of political ecology in the 1970s and 1980s. The adaptation concept, however, was 'rebooted' with the resilience and adaptive systems approaches since the 199os, and has as Thomas Bassett and Charles Fogelman (2013) observe - experienced a strong déjà vu moment in recent literature on climate change. This observation resonates with mainstream research literature on pastoralism, which has 
shifted from approaches ranging from cultural ecology and political ecology to socio-ecological resilience, most recently. Informed by earlier functionalist assumptions about stability and aversion to change, this has shaped the genre's perspective on social and economic change as primarily triggered by forces apparently external to and largely uncontrollable by local actors. Such framings tend to deny history and conceal the (well-established) fact that today's 'pastoralists' have historically navigated a wide variety of livelihoods and identities (Waller 1985). Plus ça change, plus c'est la même chose?

To be sure, adaptation is also understood as an outcome actively shaped by communities. Yet, the underlying notion is that of stable, closed-knit communities, often envisioned - as Edwin Wilmsen (1989:3) puts it for foraging societies - in "an endless, aboriginal continuity of social relations". Adaptation, Wilmsen (1989: 62) notes, "becomes in such a schema merely a retrospective assessment of survival, or perhaps of Tylorian Survivals". I do not want to insinuate that contemporary researchers of pastoralism have fallen into the trap of linear evolutionary thinking. However, the problem persistently reappears when we speak about, try to define, or categorize 'pastoralists'.

It has long been recognized that it is difficult, even impossible, to define who is and who is not a pastoralist, since narrow definitions tend to ignore enormous variations over time and across space (Homewood 2008). The inherent flexibility - or 'strategies for survival' (Anderson 2002: 80) - involved in livelihoods primarily based on herding should serve as an objection to any simple definition. Based on his study of nomadism in Iran, for example, Philip Carl Salzman dismisses any sort of ideal definition of pastoralism as an 'oversimplification' that "ignore[s] the many subtle and gross variations" (Salzman 1972: $67)$. Already in the 1980s, the Dyson-Hudsons proposed removing 'nomadic' from the analytic category 'nomadic pastoralism' to foster more dynamic perspectives on the phenomenon (Dyson-Hudson and Dyson-Hudson 1980).

While the "association with domestic grazing animals" is certainly key to pastoralism, as Katherine Homewood (2008: 1) stresses, more recent approaches move away from purely production-related definitions. Dorothy Hodgson (2000: 6), for example, uses pastoralism "to refer to those people for whom pastoralism is an ideal, if not a reality", while Michael Bollig and Michael Schnegg (2013) propose a set of indicators - labour, capital, and worldview - to identify degrees to which a person, a household, or a community could be defined as engaged in predominantly pastoralist livelihood strategies. Such attempts to escape narrow production-related determinism, however, still suggest that we can meaningfully equate identities, social organization, and economic practice. Such categories - useful shortcuts as they sometimes may be - tend to reify, essentialize, and create alterity, and ultimately (re)create the image of 
the constant herder. I could not therefore agree more with Salzman (2004: 40), who insists that "nomads [or for that matter pastoralists] are not a kind of people but different kinds of people who use a particular strategy."

\section{3}

\section{Towards Differentiated Societies and Pastoralism as Practice}

My point should be clear: I am suggesting that we drop the term 'pastoralists' from our analytical frameworks. I not only suggest this because it is increasingly problematic to confine people into imagined forms of social membership (Ferguson and Li 2018), or because of recent debates in anthropology that problematize the use of predefined concepts and categories altogether (Rees 2018). I argue that the social category, 'pastoralists', is intimately connected with reductionist notions of pre-capitalist livelihoods and problematic notions of environmental adaptationism. To arrive at a more nuanced understanding of the social transformations affecting the people formerly known as pastoralists, I propose to speak of (socio-economically) differentiated societies engaged in agrarian livelihood strategies, and of pastoralism as a continually shifting set of practices and livelihood strategies. In short, pastoral practices, not people, are distinct. ${ }^{1}$

The suggestion is inspired by contemporary hunter-gatherer research, which reveals that there are elaborate ways of addressing the problem of outdated categories. Thomas Widlok (2016: 141), for example, suggests that scholars "treat 'hunting and gathering' as a property of situations and not of groups or economic systems at large". This opens up research perspectives beyond the traditional field, for example on urban foraging in post-socialist Poland (Rakowski 2016), and allows us to build models that clarify the links between various environments and human lifeways over space and time (Widlok 2016). Such proposals, however, are beyond the scope of this chapter, and I conclude with my modest suggestion to qualify pastoralism as a situated set of socioeconomic practices. These practices are employed by different people at different times and to varying degrees. They include, among others, spatial mobility, specific ways of coping with uncertainty, and flexible institutions - in short, practices that take advantage of environmental variability (cf. Krätli 2019; Scoones 2020).

1 A similar argument is made by Mustafa Babiker (2001: 141). I am well aware that it is often difficult to avoid the use of short-hand terms such as pastoralists. Sometimes people also selfdescribe or even self-essentialize as pastoralists. Nevertheless, it is important to be aware of the critical distinction between shifting practices and reified kinds of people. 
Many current as well as future developments in the African drylands raise new analytical challenges for which the classic literature on pastoralism is of limited use. New research and debates are necessary, particularly with regard to changes in land tenure, inequality, or 'de-pastoralization' (Caravani 2018). New perspectives, such as those offered by critical agrarian studies (Bernstein 2010; Borras 2009), are needed to address - among other things - issues of accumulation, poverty, class formation, and the increasing integration of pastoral practices into (global) markets.

To speak of differentiated societies, rather than of pastoralists, encourages researchers to think outside the box and to consider socio-economic change as a series of possible paths to take, rather than a priori threats to the future.

\section{Acknowledgements}

I would like to thank Michael Bollig, Jonathan DeVore, Britta Klagge, Thomas Widlok and Steven van Wolputte, as well as two anonymous reviewers, for their helpful insights and suggestions.

\section{References}

Abbink, J., K. Askew, D. F. Dori, E. Fratkin, E. C. Gabbert, J. G. Galaty, S. LaTosky, J. Lydall, H. A. Mahmoud, J. Markakis, G. Schlee, I. Strecker and D. Turton. 2014. Lands of the Future: Transforming pastoral lands and livelihoods in eastern Africa. Working paper 154, Max Planck Institute for Social Anthropology, Halle, Germany.

Anderson, D. M. 2002. Eroding the commons. The politics of ecology in Baringo, Kenya 1890-1963. Oxford: James Currey.

Anderson, D. M. and M. Bollig. 2016. "Resilience and collapse: Histories, ecologies, conflicts and identities in the Baringo-Bogoria basin, Kenya." Journal of Eastern African Studies, 10, 1: 1-20.

Anderson, D. M. and V. Broch-Due (Eds). 1999. The poor are not us. Poverty and pastoralism in eastern Africa. Oxford: James Currey.

Babiker, M. 20o1. "Resource competition and conflict: Herder/farmer or pastoralism/ agriculture?" In African pastoralism. conflict, institutions and government, edited by M. A. Salih, T. Dietz and A. G. M. Ahmed, 134-144. London: Pluto Press.

Barth, F. 1961. Nomads of South Persia. The Basseri Tribe of the Khamseh Confederacy. Oslo: Oslo University Press.

Bassett, T. J. and C. Fogelman. 2013. "Déjà vu or something new? The adaptation concept in the climate change literature." Geoforum, 48: 42-53. 
Bernstein, H. 2010. Class dynamics of agrarian change, agrarian change and peasant studies. Halifax: Fernwood Publishers.

Bollig, M. 2006. Risk management in a hazardous environment. A comparative study of two pastoral societies. New York: Springer.

Bollig, M. and M. Schnegg. 2013. "Introduction: Specialisation and diversification among African pastoral societies." In Pastoralism in Africa. Past, present and future, edited by M. Bollig, M. Schnegg and H.-P. Wotzka, 1-28. New York: Berghan.

Borras, Saturnino M., Jr. 20o9. "Agrarian change and peasant studies: Changes, continuities and challenges - an introduction." The Journal of Peasant Studies, 36, 1: $5^{-31 .}$

Caravani, M. 2018. "'De-pastoralisation' in Uganda's Northeast: From livelihoods diversification to social differentiation." The Journal of Peasant Studies, 46, 7: 1323-1346.

Catley, A., J. Lind and I. Scoones (Eds). 2013. Pastoralism and development in Africa: Dynamic change at the margins. London: Routledge.

Dyson-Hudson, R. 1980. "Toward a general theory of pastoralism and social stratification." Nomadic Peoples, 7: 1-7.

Dyson-Hudson, R. and N. Dyson-Hudson. 1980. "Nomadic pastoralism." Annual Review of Anthropology, 9: 15-61.

Ensminger, J. 1992. Making a market. The institutional transformation of an African society. Cambridge: Cambridge University Press.

Evans-Pritchard, E. E. 1987 [1940]. The Nuer. A description of the modes of livelihood and political institutions of a Nilotic people. Oxford: Oxford University Press.

Ferguson, J. and T. M. Li. 2018. Beyond the "proper job": Political-economic analysis after the century of labouring man. Working paper 51. Institute for Poverty, Land and Agrarian Studies, University of the Western Cape.

Fratkin, E. 1991. Surviving drought and development: Ariaal pastoralists of northern Kenya (Conflict and social change series). Boulder: Westview Press.

Fratkin, E. and E. A. Roth (Eds). 2005. As pastoralists settle. Social, health, and economic consequences of pastoral sedentarization in Marsabit District, Kenya. New York: Kluwer Academic Publishers.

Galaty, J. G. 1994. "Ha(l)ving land in common: The subdivision of Maasai group ranches in Kenya." Nomadic Peoples, 34/35: 109-122.

Galaty, J. G., D. Aronson, P. C. Salzman and A. Chouinard. 1981. The future of pastoral peoples: Proceedings of a conference held in Nairobi, Kenya, 4-8 August 1980. Ottawa: International Development Research Centre.

Galvin, K. A. 2009. "Transitions: Pastoralists living with change." Annual Review of Anthropology, 38: 185-198.

Galvin, K. A., R. S. Reid, R. H. Behnke Jr. and T. N. Hobbs (Eds). 20o8. Fragmentation in semi-arid and arid landscapes. Consequences for human and natural systems. Dordrecht: Springer. 
Herskovits, M. J. 1926. “The cattle complex in East Africa." American Anthropologist, 28, 1: $230-272$.

Hinde, S. L. and H. Hinde. 1901. The last of the Maasai. London: Heinemann.

Hodgson, D. L. 2000. "Gender, culture and the myth of the patriarchal pastoralist." In Rethinking pastoralism in Africa: Gender, culture and the myth of the patriarchal pastoralist, edited by D. L. Hodgson, 1-28. Oxford: James Currey.

Hodgson, D. L. 2001. Once intrepid warriors: Gender, ethnicity, and the cultural politics of Maasai development. Bloomington: Indiana University Press.

Hogg, R. 1986. "The new pastoralism: Poverty and dependency in northern Kenya." Africa Today, 56, 3: 319-333.

Holtzman, J. D. 2003. "In a cup of tea: Commodities and history among Samburu pastoralists in northern Kenya." American Ethnologist, 30, 1: 136-155.

Homewood, K. 2008. Ecology of African pastoralist societies. Oxford: James Currey.

Homewood, K., P. Kristjanson and P. C. Trench (Eds). 20o9. Staying Maasai? Livelihoods, conservation and development in East African rangelands. New York: Springer.

Korf, B., T. Hagmann and R. Emmenegger. 2015. "Re-spacing African drylands: Territorialization, sedentarization and indigenous commodification in the Ethiopian pastoral frontier." The Journal of Peasant Studies, 42, 5: 881-901.

Krätli, S. 2019. Pastoral development orientation framework: Focus on Ethiopia. Aachen: Bischöfliches Hilfswerk Misereor.

Lesorogol, C. K. 2008. Contesting the commons: Privatizing pastoral lands in Kenya. Ann Arbor: Michigan University Press.

Lind, J., D. Okenwa and I. Scoones. 2020. "Introduction: The politics of land, resources and investment in eastern Africa's pastoral drylands." In Land, investment and politics: Reconfiguring East Africa's pastoral drylands, edited by J. Lind, D. Okenwa and I. Scoones, 1-32. Woodbridge: James Currey.

Little, P. D. 1985. "Social differentiation and pastoralist sedentarization in northern Kenya." Africa, 55, 3: 243-261.

Little, P. D. 1992. The elusive granary. Herder, farmer, and the state in northern Kenya, Cambridge: Cambridge University Press.

Little, P. D. 2003. "Rethinking interdisciplinary paradigms and the political ecology of pastoralism in East Africa." In African savannas. Global narratives and local knowledge of environmental change, edited by T. J. Bassett and D. Crummey, 161-177. Oxford:James Currey.

Little, P. D. 2014. Economic and political reform in Africa: Anthropological perspectives. Bloomington: Indiana University Press.

Little, P. D., K. Smith, B. A. Cellarius, D. L. Coppock and C. Barrett. 20o1. "Avoiding disaster: Diversification and risk management among East African herders." Development and Change, 32, 3: 401-433. 
Little, P. D., J. McPeak, C. B. Barrett and P. Kristjanson. 2008. "Challenging orthodoxies: Understanding poverty in pastoral areas of East Africa." Development and Change, 39, 4: 587-611.

McCabe, J. T. 2004. Cattle bring us to our enemies. Turkana ecology, politics, and raiding in a disequilibrium system. Ann Arbor: University of Michigan Press.

McCabe, J. T., P. W. Leslie and L. DeLuca. 2010. "Adopting cultivation to remain pastoralists: The diversification of Maasai livelihoods in northern Tanzania." Human Ecology, 38, 3: 321-334.

Mkutu, K. 2008. Guns and governance in the Rift Valley. Pastoralist conflict and small arms. Oxford: James Currey.

Moritz, M. 2012. "Pastoral intensification in West Africa: Implications for sustainability." Journal of the Royal Anthropological Institute, 18, 2: 418-438.

Rakowski, T. 2016. Hunters, gatherers, and practitioners of powerlessness. An ethnography of the degraded in postsocialist Poland. New York: Berghahn Books.

Rappaport, R. A. 1984. Pigs for the ancestors. Ritual in the ecology of a New Guinea people. Long Grove: Waveland Press.

Rees, T. 2018. After ethnos. Durham: Duke University Press.

Rigby, P. 1985. Persistent pastoralists. Nomadic societies in transition. London: Zed Books.

Salzman, P. C. 1972. "Multi-resource nomadism in Iranian Baluchistan." Journal of Asian and African Studies, 7, 1: 6o-68.

Salzman, P. C. 1980. "Introduction: Processes of sedentarization as adaptation and response." In When nomads settle. Processes of sedentarization as adaptation and response, edited by P. C. Salzman, 1-19. New York: Praeger.

Salzman, P. C. 2004. Pastoralists. Equality, hierarchy, and the state. Boulder, CO: Westview Press.

Schareika, N. 1994. Die soziale Bedeutung der Rinder bei den Fulbe (Benin). Münster: LIT Verlag.

Schlee, G. 1989. Identities on the move: Clanship and pastoralism in northern Kenya. Manchester: Manchester University Press.

Schneider, H. K. 1959. "Pakot resistance to change." In Continuity and change in African cultures, edited by W. S. Bascom and M. J. Herskovits, 144-165. Chicago: Chicago University Press.

Scoones, I. 202O. "Pastoralists and peasants: Perspectives on agrarian change." The Journal of Peasant Studies, 48, 1: 1-47.

Spencer, P. 1965. The Samburu: A study of gerontocracy in a nomadic tribe. Berkeley: University of California Press.

Spencer, P. 1998. The pastoral continuum. The marginalization of tradition in East Africa. Oxford: Oxford University Press. 
Waller, R. 1985. "Ecology, migration, and expansion in East Africa." African Affairs, 84, 336: 347-370.

Watts, M. J. 2015. "Now and then: The origins of political ecology and the rebirth of adaptation as a form of thought." In The Routledge handbook of political ecology, edited by T. Perreault, G. Bridge and J. McCarthy, 19-5o. Abingdon: Routledge.

Widlok, T. 2016. "Hunter-gatherer situations." Hunter Gatherer Research, 2, 2: 127-143.

Wilmsen, E. 1989. Land filled with flies: A political economy of the Kalahari. Chicago: University of Chicago Press.

Zimmerer, K. S. 1994. "Human geography and the 'new ecology': The prospect and promise of integration." Annals of the Association of American Geographers, 84, 1: 108-125. 